\title{
Determinants of Rural Households' Food Security in Shiselweni Region, Swaziland: Implications for Agricultural Policy
}

\author{
SinikiweKuwenyi ${ }^{1}$, Francois I. Kabuya ${ }^{2}$, Micah B. Masuku ${ }^{3}$ \\ ${ }^{1}$ AgriculturalEconomics and Management Department, University of Swaziland, Swaziland \\ ${ }^{2}$ Agricultural Economics and Management Department, University of Swaziland, Swaziland \\ ${ }^{3}$ Agricultural Economics and Management Department, University of Swaziland, Swaziland
}

\begin{abstract}
This paper attempts to identify the fundamental factors that are key determinants of rural households' food security in Shiselweni region, using cross-sectional data and a 2-stage sampling technique to select randomly 141 households from 4 constituencies (Tinkhundla).The coping strategies, head count ratios, and logistic regression modelwere used to obtain the households' food security status and determine significantfactors influencing food security, respectively.Results revealthat $51.7 \%$ of the rural households in the regionare food insecure. Logistic regression results show that age, gender, land, and livestock ownership variablesare significantly associated with households' food security at 5 per cent $(p<0.05)$. This study also indicates that $46 \%$ of households are likely to employ different coping strategies (reducing food consumption, skipping meals, consuming less than 3 meals per day) as their survival strategy. The implication for policy is that when moving forward in designing and implementing pro-agricultural policy, policy makers should emphasize on improving food availability and accessibility to rural households.
\end{abstract}

Keywords: Coping strategies, food security, logistic regression, pro-agricultural policy, Swaziland

\section{Introduction}

The Food and Agriculture Organization [1] defines food security as the ability of all people to have access to nutritious food for a healthy life.Food security is viewed in terms of food availability, access, utilization and stability of access [2]. Food security measure matters because the national and household levels are assessed differently [3].

Almost a billion people worldwide do not have access to nutritious food [4]. According to Labadarios et al. [5], about 250 million people in sub-Saharan Africa are under-nourished and spend at least a day without food.They went on to point out that African countries are also struggling to maintain a constant and stable access to food mainly because population growth has been higher than food production. The number of food insecure individuals has been increasing steadily since the 1990s [6].Swaziland has not been an exception to this worldwide food insecurity tragedy.

\subsection{Why is food security important?}

Results of the 2013 Cost of Hunger in Africa study indicate that Swaziland's economy loses up to 3.1 per cent of its GDP annually associated to chronic under-nutrition [7]. Food security becomes an issue for concern and for possible policy response when it points to nutritional deficiencies and increased hunger and poverty [8].Understanding the determinants of food security can help design optimal policies that may prevent these losses in the future.

There are a number of studies that looked at food security issues in Swaziland. Masuku and Sithole [9] study the impact of HIV and AIDS on agriculture and food security in Swaziland. They find that HIV and AIDS pose a developmental problem and challenge the ideals of a long-term strategy for poverty reduction and food security in the country.

Vella [10] studies food and water security in Swaziland: potential for crises. The author finds that (1) the country's food insecurity is, in part, due to a poor crop marketing system, which is controlled by the state and (2) lack of food purchasing power, stemming from decades of entrenched poverty. Mabuza et al. [11] study the impact of food aid on maize prices and production in Swaziland. They find that the food aid from NonGovernmental Organizations (NGOs) and government social grants have played a very important role in providing food to households on a short-term or temporary basis. However, the amount received under this social programme is not enough to make the recipients food secure. While the previous studies cover the populations of all the four regions in the country (Manzini, Hhohho, Lubombo and Shiselweni), this paper looks at the determinants of rural population's food security in the Shiselweni region-implications for agricultural policy. 


\subsection{Food security in Swaziland}

Food security is a concern especially among the poor living in the rural areas [1]. Since gaining independence in 1968, Swaziland has consistently been a food deficit country. It is reliant upon imports and international assistance to satisfy the food requirements of its population[10]. High unemployment, economic crisis and the rising food prices have been pushing more people into a state of food insecurity [12].

\subsection{Swaziland's key points}

Swaziland has a population of around 1.2 million people, the majority of whom occupy rural farms on Swazi National Land (SNL). Around 63 per cent of Swazis live in poverty [13]. The country has the highest rate of HIV/AIDS infection in the world; 26.5 per cent of the population aged between 15 and 49 years are HIV positive [10]. The country has four administrative regions as shown in Fig. 1.

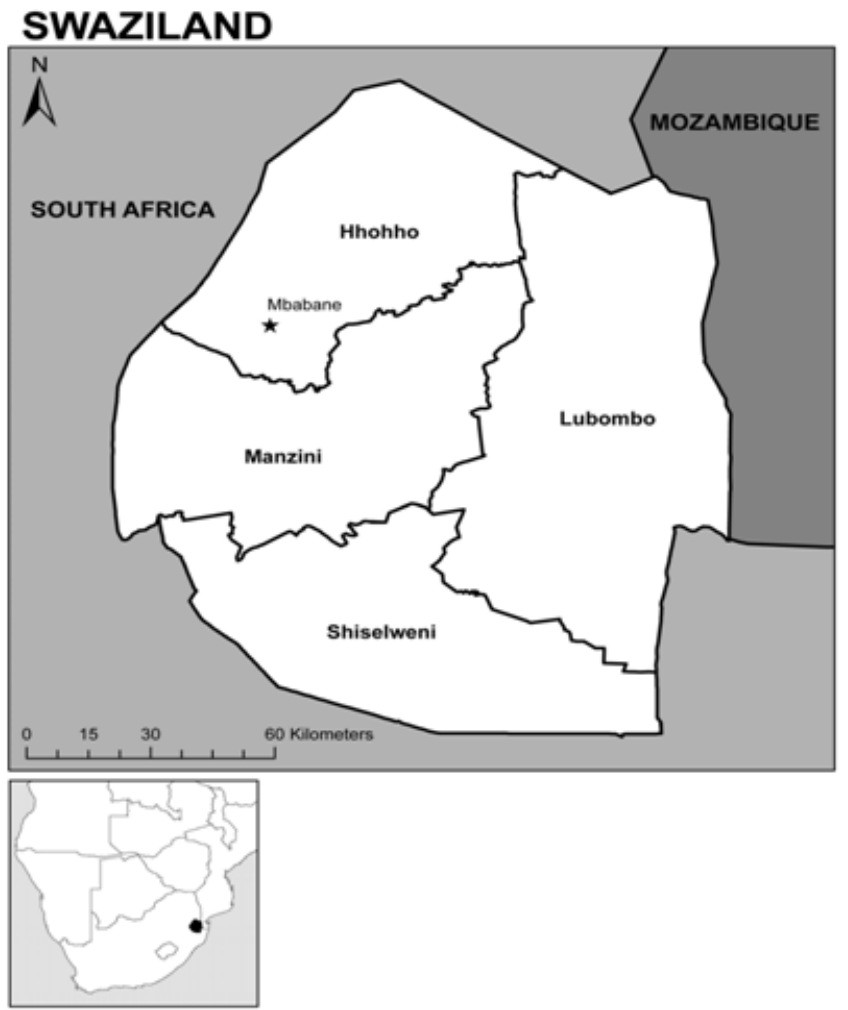

Figure 1 Swaziland's Administrative Regions [13]

\section{Literature Review}

Feleke et al. [14] came up, in their determinants of households' food security study in Southern Ethiopia, with a number of factors affecting food security such as age, education, sex, unemployment rate and income level. Liverpool-Tessie et al.[2] found that factors affecting food security were grouped as social, economic, demographic, and policy related factors.Demographic factors include household size, household land holdings. Cyclones, drought and land degradation are considered as environmental factors.Social and economic factors can be war, productive assets ownership, employment status, income, and use of public goods by both government and local residents.

The urban poor in South Africa are affected much more by food insecurity than the rural households are.The rural dwellers have access to natural resources mainly land and water, which they can use to produce food[15]. In contrast to this, Matshe [16]argued that the rural dwellers are the most food insecure due to their dependency on income generated by natural products. Ellisand Mdoe [17]agreedwith [16] that rural households in Tanzania were worse off in terms of poverty and food security than urban residents were.

Vulnerability Assessment Committeeand World Food Programme [18] report that about 67\% of sampled residents of Shiselweni region indicate that they frequently go to bed without food. The study found that $38 \%$ of residents in Shiselweni region were extremely food insecure while in Lubombo region 22\%, Hhohho 21\% and Manzini region 11\% were highly food insecure. This had shown that Shiselweni residentswere most vulnerable to food insecurity. 
Food insecurity in Ethiopia is high for households above 45 old years, and food security decreased with age. Female-headed households are worse off in terms of food security compared to their male counterparts who are engaged in income generating activities both on the farm and off farm [19].

Gender of household heads in Bangladesh has no significant effect on food security due to lower number of female households; education is associated positively with food security as householdheads with more human capital are prone to suffer less food insecurity[20].This aligns withCock's findings [21] that education is important determinant of food security in Limpopo rural areas, South Africa.

There exists a negative relationship between food security and household size [22].Altman et al. [3]observe that household size is one of the most important socio-economic determinants of food insecurity because it increases the number of consumers within the household; hence putting pressure on the food within the household.

Swaziland's study in the urban areas shows that there is a link between type of house owned by the family and food security. Those who are able to build brick houses with tiles/ iron roof are considered food secure while those living in tin/ shack houses are mostly found to be food insecure [18]. Faridi and Wadood [20] noted that house owners were more food secure than those who were renting or homeless as they could afford to buy food.

\subsection{The Study Area}

\section{Methods}

The study was conducted in Shiselweni region, where most households reside in the rural areas [13]. The region is divided into 14 constituencies (Tinkhundla) namely, Gege, Hosea, Kubuta, Maseyisini, Matsanjeni South, Mtsambama, Ngudzeni, Nkwene, Sandleni, Shiselweni I, Shiselweni II, Sigwe, Somntongo and Zombodze. Theseconstituencies are each divided into chiefdoms ranging from 5-9 chiefdoms.

\subsection{Data}

\subsubsection{Sampling Technique}

The following formula from [23] was used to obtain a representative sample:

$$
\mathbf{N}=\frac{z^{2} p q}{d^{2}}
$$

Where

$N=$ sample sized desired, $Z=$ the standard normal set at 1.96 , which corresponds to $95 \%$ confidence interval, $d=$ degree of accuracy required set at $0.05, p=$ the estimated proportion of target population with the desired attribute (food secure), and $q=1-p$. A two-stage sampling technique was used. The first stage involved the purposive selection of 4 out of the 14 constituencies in the region. Each constituency (Tinkhundla) was given a random number from 1 to14 on a list. The second stage involved random selection of 2 chiefdoms perconstituency (Tinkhundla). A sample of 141 households was drawn from the selected constituencies.

\subsubsection{Data analysis}

Descriptive statistics (frequencies, percentages, means, medians, standard deviations) and bivariate analysis using cross tabulations were conducted to describe the demographic structure of households. The cross tabulations were done to identify the relationship between food security and independent variables. Differences in proportions were assessed by chi-square analysis. A p-value of less than 0.05 ( $\mathrm{p}$-value $<0.05$ ) was considered significant. Correlates with a p-value $<0.10$ were also retained. The index of household coping strategies was also used to measure how households adapt to the threats of food shortage.

Logistic regression model was used to identify the factors affecting food security in the region. The outcome variable was food security with a value of 1 denoting positive answer (food security) and 0 indicating a negative answer (food insecurity). Therefore, the probability of being food secure can be written as follows:

$\mathrm{P} i=\epsilon(\gamma=1) \mid \mathrm{X} i=\left(\frac{1}{1+e^{-\left(\beta_{0}+\beta_{1} X_{i}\right)}}\right)$

taking $\beta_{1}+\beta_{2} X_{i}$ to be

$z i$ and the equation becomes $\operatorname{Prob}($ foodsecure $)=\left(\frac{1}{1+e^{-z i}}\right)=\left(\frac{e^{z i}}{1+e^{z i}}\right)$

Where $z i=\beta_{0}+\beta_{1} X_{1}+\beta_{2} X_{2}+\beta_{3} X_{3}+\cdots \beta_{n} X_{n},(3)$

Which implies a linear combination of correlates, $X_{\mathrm{i}}$ with $\mathrm{i}$ ranging from 1 to $\mathrm{n}$ and the $\beta_{\mathrm{i}}$ (i=0 to $\mathrm{n}$ ) represents the coefficients for the correlates. The value of $z i$ ranges from $-\infty$ to $+\infty$ and therefore,P $i$ ranges between 0 and 1. Given that $\mathrm{P} i$ is the probability of being food secure then 1-Pi becomes the probability of being food insecure. 


\subsection{Model Specification}

For the purpose of empirical estimation, the logistic regression model is specified as follows: $z i=\beta_{0}+\beta_{1} X_{1}+\beta_{2} X_{2}+\beta_{3} X_{3}+\beta_{4} X_{4}+\beta_{5} X_{5}+\beta_{6} X_{6}+\beta_{7} X_{7}+\beta_{8} X_{8}+\beta_{9} X_{9}+\beta_{10} X_{10}+$

$\beta_{11} X_{11}+\beta_{12} X_{12}+\mathrm{u}_{\mathrm{i}}$

Where

$\mathrm{X} 1=$ age of household head

$\mathrm{X} 2$ = gender of household head

$\mathrm{X} 3$ = household size

$\mathrm{X} 4=$ household head marital status

X5 $=$ household head education

$\mathrm{X} 6=$ household head employment status

$\mathrm{X} 7=$ household head land ownership

$\mathrm{X} 8=$ household head assets ownership

$\mathrm{X} 9=$ household head health status

$\mathrm{X} 10=$ household head type of house

$\mathrm{X} 11=$ household head income source

$\mathrm{X} 12=$ household head livestock ownership status

\subsection{Socioeconomic Status of Households}

\section{Results And Discussion}

Majority of households surveyed were males $(60.3 \%)$. A greater number of households are below 40 years old and fall within the family size bracket of 4-6. The mean age of households is 46 years implying that over $70 \%$ of households are below retirement age. The literacy level is low as $52.5 \%$ of households have primary education that prevents them from being productive in generating income. This finding is consistent with Omotesho's observation [22] indicating that educated household heads have greater chance of providing incomes and food for their families.

Most of the respondents are married (61.7\%).The unemployed in the region is $(76.6 \%)$, which aligns with the COS's statistics [13] that indicate that the rural unemployment in Swaziland is about $75 \%$. Whereas, $60.3 \%$ and $86.5 \%$ of the households own land below one hectare and different types of assets (hoe, spade, hosepipe, wheelbarrow, harrow), respectively. This small size of land does not allow them to produce enough staple food (maize) to sustain their food availability. More than $70 \%$ of households in Shiselweni region own at least one type of domestic animal. Chicken is the most owned livestock (62.1\%), and 37.1\% of households own cattle. Regional Hunger and Vulnerability Programme [24] also finds that chicken is the most type of livestock in rural households as it is a source of meat when the household cannot afford to purchase from the market.

Table 4.1Socioeconomic Status of Households

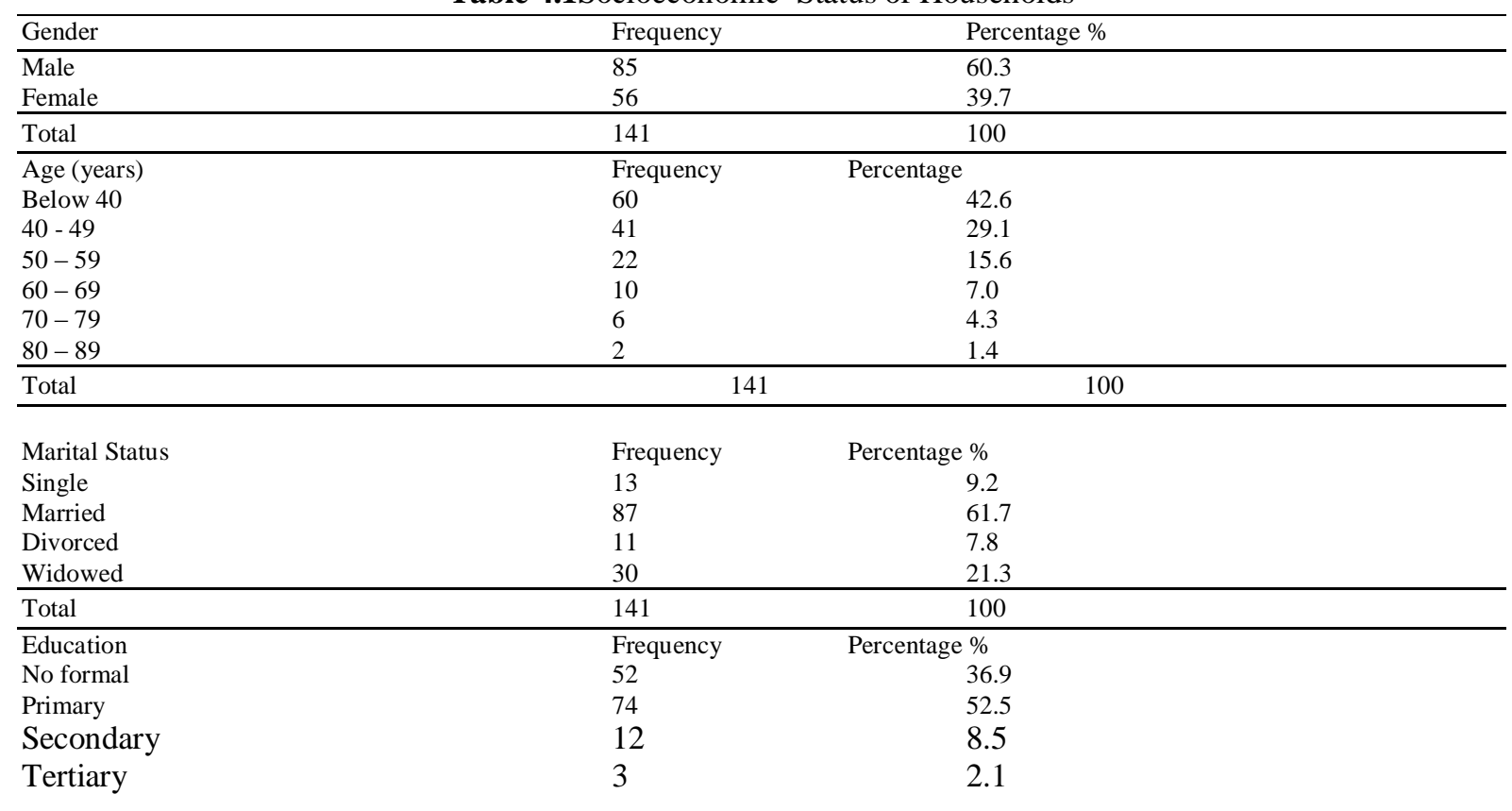




\begin{tabular}{|c|c|c|}
\hline Household size & \multicolumn{2}{|r|}{ Percentage $\%$} \\
\hline $1-3$ & 31 & 22.0 \\
\hline $4-6$ & 68 & 48.2 \\
\hline $7-9$ & 30 & 21.3 \\
\hline $10-13$ & 12 & 8.5 \\
\hline Total & 141 & 100 \\
\hline \multicolumn{3}{|l|}{ Health Status } \\
\hline Good & 115 & 81.6 \\
\hline Poor & 26 & 18.4 \\
\hline Total & 141 & 100 \\
\hline Assets Ownership & Frequency & Percentage $\%$ \\
\hline Yes & 122 & 86.5 \\
\hline No & 19 & 13.5 \\
\hline Total & 141 & 100 \\
\hline Livestock Ownership & Frequency & Percentage $\%$ \\
\hline Yes & 101 & 71.6 \\
\hline No & 40 & 28.4 \\
\hline Total & 141 & 100 \\
\hline Employment & Frequency & Percentage $\%$ \\
\hline Employed & 33 & 23.4 \\
\hline Unemployed & 108 & 76.6 \\
\hline Total & 141 & 100 \\
\hline Land Ownership & Frequency & Percentage $\%$ \\
\hline None & 27 & 19.1 \\
\hline Below 1 hectare & 85 & 60.3 \\
\hline Above 1 hectare & 29 & 20.6 \\
\hline Total & 141 & 100 \\
\hline Type of House & Frequency & Percentage $\%$ \\
\hline Stone and stick & 81 & 57.4 \\
\hline Brick & 39 & 27.7 \\
\hline Shack & 21 & 14.9 \\
\hline Total & 141 & 100 \\
\hline Source of Income & Frequency & Percentage $\%$ \\
\hline Own farm & 59 & 41.8 \\
\hline Off farm & 58 & 41.1 \\
\hline Remittances & 7 & 5.0 \\
\hline Grants & 17 & 12.1 \\
\hline Total & 141 & 100 \\
\hline
\end{tabular}

\subsection{The Strategy Coping Index}

Calculating a weight sum of the different strategies, which is one of the strategies designed by [25] was used to obtain the households' food security status.Frequency of each coping strategy was ranked from 1-5 whereby 1 is never and 5 is always. The lower the sum, the more food secure is the household. It is observed that $42.6 \%$ of households are highly food secure with $5.7 \%$ being on the borderline. Severe food insecure and least food insecure households represent $32.6 \%$ and $19.1 \%$, respectively as shown in Table 4.2

Table 4.2 The Coping Strategy index

\begin{tabular}{lcccc}
\hline Classification of Food Security & HCSI score & Frequency & $\%$ & Total \% \\
\hline & & & & \\
Highly food secure & $8-14$ & 60 & 42.6 & 5.7 \\
Moderately food secure & $16-19$ & 8 & 19.1 & 48.3 \\
Least severe food insecure & $20-24$ & 27 & 32.6 & 51.7 \\
Severe food insecure & $25-40$ & 46 & & \\
\hline
\end{tabular}

HCSI (Household Coping Strategies Index)

4.3 The Percentage Distribution of Households Coping Strategies

Households in region reveal some coping strategies used when facing food security concern. More than $48 \%$ of sampled residents indicate that they sometimes consume less than 3 meals per day, while $45 \%$ reduce their food consumption, and $44.7 \%$ of them consume less food than required as indicated in Table 4.3. 
Table 4.3 The Percentage Distribution of Households' Coping Strategies

\begin{tabular}{|c|c|c|c|c|c|}
\hline $\begin{array}{l}\text { Coping Strategies } \\
\%\end{array}$ & $\begin{array}{l}\text { Never } \\
\%\end{array}$ & $\begin{array}{l}\text { Rarely } \\
\%\end{array}$ & $\begin{array}{l}\text { Some } \\
\%\end{array}$ & & $\begin{array}{l}\text { Always } \\
\%\end{array}$ \\
\hline Consume less than 3 meals & 39.7 & 1.4 & 48.9 & 3.5 & 6.4 \\
\hline Reduce quantity of food & 48.2 & 5.7 & 42.6 & 0.7 & 2.8 \\
\hline $\begin{array}{l}\text { Reduce own consumption } \\
\text { Reduce quantity of food }\end{array}$ & 44.7 & 0.7 & 45.4 & 2.8 & 6.4 \\
\hline $\begin{array}{l}\text { served to children } \\
\text { Skip own meals due to }\end{array}$ & 44 & 3.5 & 46.8 & 2.8 & 2.8 \\
\hline $\begin{array}{l}\text { lack of food } \\
\text { Consume less food than }\end{array}$ & 44.7 & 2.1 & 43.3 & 5.7 & 3,5 \\
\hline $\begin{array}{l}\text { Required } \\
\text { Resort to begging due to }\end{array}$ & 44 & 2.8 & 44.7 & 3.5 & 5 \\
\hline $\begin{array}{l}\text { lack of food } \\
\text { Go to bed hungry due to }\end{array}$ & 58.2 & 5 & 31.2 & 2.8 & 2.8 \\
\hline lack of food & 53.9 & 4.3 & 37.6 & 1.4 & 2.8 \\
\hline
\end{tabular}

4.4The Head Count Index

A head count index was constructed to show the ratio of food secure and food insecure households. It is observed that 0.48 of the households are food secure while 0.51 of the households are food insecure as indicated in Table 4.4

Table 4.4The Head Count Index

\begin{tabular}{llll}
\hline Head Count & Food Secure & Food insecure & Total \\
\hline Ratio & 0.483 & 0.517 & - \\
Percentage & 48.3 & $51-7$ & 100 \\
Number of households & 68 & 73 & 141 \\
\hline
\end{tabular}

4.5 The Logistic Regression Results

The Hosmer-Lemeshowstatistic test (7.63) indicates that the model adequately fits the data; and the average marginal effect (0.51) measures the expected change in the probability of being food secure due to change in the regressors. The table 4.5 shows that age, gender, land size above hectare and livestock significantly $(p<0.05)$ influence the household food security status. Age has a negative coefficient indicating that as household gets older the probability of being food secure decreases. This result agrees with [26] who found that age was negatively related to food security. Male headed households are likely more food secure than female headed households are as women do not have access to resources.

The households with land size above hectare are food secure as land ownership is a very important factor in rural settings. The finding confirms the Omotesho's [22] that reported a significant positive effect on food security in the rural households of Kwara State in Nigeria. The study also finds that households owning livestock are likely to be food secure than those without any livestock. Haile et al. [27] found the similar results in Ethiopia. Whereas, education, employment, and income are found to be insignificant in determining the food security status in region. This may reflect low education level and high unemployment rate in the region under the study.Contrary to these findings, Cock et al. [21] found that education was a very important determinant of food security in the rural areas of Limpopo, South Africa. Arene and Anyaeji [28] found that income was a very important factor in determining a household's food security in Nsukka Metropolis of Enugu State, Nigeria.

Table 4.5 Logistic Regression Results

\begin{tabular}{|c|c|c|c|c|c|c|}
\hline Variables & Coefficient & $\begin{array}{l}\text { standard } \\
\text { Error }\end{array}$ & Z-value & $\mathrm{P}>|\mathrm{z}|$ & Odds Ratio & $\begin{array}{l}\text { Marginal } \\
\text { effect }\end{array}$ \\
\hline Age & -0.4237 & 0.018 & -2.31 & $0.021 * *$ & 0.96 & -0.0075 \\
\hline Gender & 1.1022 & 0.532 & 2.12 & $0.034^{* *}$ & 3.01 & 0.1948 \\
\hline Marital status & 0.1385 & 0.611 & 0.26 & 0.795 & 1.15 & 0.0245 \\
\hline Primary education & 0.3829 & 0.459 & 0.83 & 0.404 & 1.47 & 0.0677 \\
\hline Higher education & 0.1628 & 0.817 & 0.2 & 0.849 & 1.18 & 0.0288 \\
\hline Employment & 0.4480 & 0.546 & 0.82 & 0.412 & 1.57 & 0.0792 \\
\hline Own farm income & -0.1363 & 0.714 & -0.19 & 0.849 & 0.87 & -0.0241 \\
\hline Off farm income & -0.2530 & 0.745 & -0.34 & 0.734 & 0.78 & -0.0447 \\
\hline Health status & -0.1342 & 0.607 & -0.22 & 0.825 & 0.87 & -0.0237 \\
\hline Livestock ownership & 1.0935 & 0.557 & 1.96 & $0.05^{* *}$ & 2.98 & 0.1933 \\
\hline Household asset & & & & & & \\
\hline ownership & -0.7090 & 0.777 & -0.91 & 0.362 & 0.49 & -0.1253 \\
\hline Dwelling & 0.5203 & 0.505 & 1.03 & 0.303 & 1.68 & 0.0920 \\
\hline Household size & -0.0127 & 0.090 & -0.14 & 0.888 & 0.99 & -0.0022 \\
\hline Hectare land & 0.0006 & 0.611 & 0 & 0.999 & 1.00 & 0.0001 \\
\hline
\end{tabular}




\begin{tabular}{|c|c|c|c|c|c|c|c|}
\hline \multicolumn{2}{|l|}{ Above hectare } & 0.9451 & 0.395 & 2.39 & $0.017 * *$ & 2.57 & \multirow[t]{2}{*}{0.1671} \\
\hline Cons & & 0.5608 & 1.403 & 0.4 & 0.689 & 1.75 & \\
\hline Log likelihood & $=$ & -71.8566 & & \multicolumn{4}{|c|}{ Number of cases $=136$} \\
\hline LR chi2 (15) & $=$ & 44.71 & & \multicolumn{4}{|c|}{ Average marginal effect $=0.515$} \\
\hline Prob>chi 2 & $=$ & 0.001 & & \multirow{2}{*}{\multicolumn{4}{|c|}{ Hosmer-Lemeshow $\operatorname{chi} 2(8)=7.63$}} \\
\hline Pseudo R2 & $=$ & 0.2373 & & & & & \\
\hline
\end{tabular}

\section{Conclusion And Policy Implication}

This paper has identified the determinants of households' food security in Shiselweni region.Although Swaziland is a middle-income country, food security remains an issue for concern and for possible policy response when it points to nutritional deficiencies and increased hunger and poverty, especially for people living in rural areas.The policy implication is that pro-agricultural policies cannot be effective unless institutional and cultural reforms, and sound pro-economic policies are implemented. The impact evaluation of Comprehensive Agriculture Policy in Swaziland (CAPS) on food security deserves future research attention.

\section{References}

[1] Food and Agriculture Organization (FAO), Rome Declaration on World Food Security Summit ActionPlan, 1996

[2] L. Liverool-Tasie, O. Kuku, and A. Ajibola, A Review of Literature on Agricultural Productivity, Social Capital and Food Security in Nigeria, NSSP Working paper, 2011

[3] M. Altman, T. Hart and P. Jacobs, Household food security status in South Africa, Agrekon, 48 (4), 2009, 345-361

[4] Food and Agriculture Organization, Food security issue (2), Swaziland 2006

[5] D. Labadarios, Z. Mchiza, and G. Weir-Smith, Food security in South Africa, Bulletin of the World Health Organization BLT (11.089243), 2011, 1-20

[6] A. Salami, Z. Brixiova, and H. Kandil Towards to food security in Africa: Challenges, policies, and the role of the African Development Bank, Africa Economic Brief 2 (2), 2011, 30-45.

[7] United Nations World Food Programme, Vulnerability and food insecurity in urban areas of Swaziland: An assessment of the impact of high prices on households in four regions, Mbabane, Swaziland, 2008

[8] T. Johnson, Food price volatility and insecurity, Council on Foreign Relations, January 16, 2013

[9] M.B. Masuku and M.M. Sithole, The impact of HIV / AIDS on food security and household vulnerability in Swaziland, Agrekon, 48 (2), 2009, $1-23$.

[10] J. Vella, Food and water security in Swaziland: Potential for crises, FDI Global Food and Water Crises Research Programme, June $14,2012$.

[11] M. L. Mabuza et al., The impact of food aid on maize prices and production in Swaziland, Agrekon, 48 (1), $2009,85-105$

[12] F. I. Kabuya, Economics for African nations, principles, problems and policies, Victoria, Canada, 2007

[13] Central Statistics Office (CSO), Swaziland demographic and health survey, Mbabane, Swaziland, 2006-7

[14] S.T. Feleke, R.L. Kilmer, and C.H. Gladwin, Determinants of household food security in Southern Ethiopia at the household level, Agricultural Economics, 33 (2), 2005, 351-363

[15] M. Baiphethi and P. Jacobs, The contribution of subsistence farming to food security in South Africa, Agrekon, 48 (4), 2010, 459482

[16] I. Matshe, Boosting smallholder production for food security: Some approaches and evidence from studies in Sub-Saharan Africa, Agrekon, 48 (4), 2009, $483-511$.

[17] F. Ellis and N. Mdoe, Livelihoods and rural poverty reduction in Tanzania, World Development, 31 (8), $2003,1367-1384$.

[18] Vulnerability Assessment Committee (VAC), Vulnerability and food insecurity in urban areas of Swaziland: An Assessment of the Impact of High Prices on Households in Four Regions, Swaziland, Mababane, Swaziland, December 2008.

[19] G. G. Gebre, Determinants of food security among households in Addis Ababa city, Ethiopia, Interdisciplinary Description of Complex Systems, 10 (2), 2012, $173-190$.

[20] R. Faridi and S. N. Wadood, An econometric assessment of household food security in Bangladesh, The Bangladesh Development Studies, 33 (3), 2010, $98-111$.

[21] N.D. Cock and al., Food security in rural areas of Limpopo province, South Africa, Unpublished manuscript, 2013.

[22] O. A. Omotesho et. Al., Determinants of food security among the rural farming households in Kwara State, Nigeria, African Journal of Agriculture, 2 (1), 2006, 1 - 15.

[23] G. D. Israel, Determining sample size, Unpublished manuscript, University of Florida, 2013.

[24] Regional Hunger and Vulnerability Programme (RHVP), Swaziland old age grant impact assessment, Mbabane, Swaziland, November 2010.

[25] J. Hoddinott, Choosing outcome indicators of household food security, Washington D.C., International Food Policy Research Institute, 1999.

[26] R. O. Babatunde, and O. S. Sholotan, Factors influencing food security status of rural farming household in North Central Nigeria, Agricultural Journal, 2 (3), 2007, 351 - 357.

[27] H. K. Haile, and G. Kudhlande, Causes of household food insecurity in Koredegaga peasant association, Oromiya Zone, Ethiopia, University of the Free State, South Africa, Unpublished manuscript, 2005.

[28] C. J. Arene, and R.C. Anyaeji, Determinants of food security among households in Nsuka Metropolis of Enugu State, Nigeria, Kistan Journal of Social Sciences, 30 (1), 2010, 1 - 30. 